\title{
The Effect of Faculty Mentoring on Career Success and Career Satisfaction
}

\author{
Ayşe ANAFARTA ${ }^{1} \&$ Çiğdem Apaydın ${ }^{2}$ \\ ${ }^{1}$ Faculty of Economics and Administrative Sciences, Akdeniz University, Antalya, Turkey \\ ${ }^{2}$ Faculty of Education, Akdeniz University, Antalya, Turkey \\ Correspondence: Çiğdem Apaydın, Faculty of Education, Akdeniz University, Antalya, Turkey. Tel: \\ 90-242-310-4632. E-mail: cigdemapaydin@akdeniz.edu.tr
}

\author{
Received: November 10, 2015 Accepted: December 15, 2015 Online Published: May 26, 2016 \\ doi:10.5539/ies.v9n6p22 \\ URL: http://dx.doi.org/10.5539/ies.v9n6p22
}

\begin{abstract}
Mentoring has received considerable attention from scholars, and in the relevant literature, a number of studies give reference to the mentoring programs developed at universities and to the mentoring relations in higher education. Yet, most of these studies either only have a theoretical basis or deal with the mentoring relationships between academic advisors and undergraduate or masters' students. Very few studies have been conducted so far on the mentoring or protégé experiences of academicians in the university setting, and the relationships between career satisfaction and career success. The aim of the current study is to examine the effect of mentoring on career success and career satisfaction of faculty members in Turkish higher education system. Participants included 445 faculty members from various universities in Turkey. The results of the study reveal that academic and psychosocial mentoring have an impact on faculty members' career satisfaction and career success. Also, psychosocial mentoring affects career success more compared to academic mentoring.
\end{abstract}

Keywords: academic mentoring, career success, career satisfaction, structural equation model (SEM), faculty

\section{Introduction}

Mentoring is an important part of higher education. The importance of mentoring is universally accepted, but most of the research on mentoring has been conducted in business sector rather than in education (Allen, Eby, Poteet, \& Lentz, 2004; Stanley \& Lincoln, 2005). Mentoring in academic setting refers to the guidance provided by an experienced professor or associate professor to a less experienced faculty member (also called protégé) on issues relating to academic traditions, resources and institutional values. Mentor in an academic setting is a person who teaches, assists, acts as a role model, and provides time, energy and material support as a source of inspiration to some less experienced faculty members. Mentors are able to prepare the protégés for new and diverse positions in an academic setting as well as assisting them in their career paths and career alternatives. This sort of mentoring entails support in academic endeavors, and more importantly, provides help to the protégé in comprehending and overcoming the political and social barriers within the department, school or faculty (Madison \& Huston, 1996).

Faculty mentoring may have various effects on the protégés' career satisfaction and their perceptions of career success. Most of the studies conducted to date have examined the effect of mentoring on career-related outcomes (Ensher, Thomas, \& Murphy, 2001), yet most of these studies either only have a theoretical basis or deal with the mentoring relationships between academic advisors and undergraduate or masters' students. Very few studies have been conducted so far on the mentoring or protégé experiences of academicians in the university setting, and on the causal relationship between faculty mentoring, career satisfaction and career success. The current study aims to examine whether there is a direct relationship between mentoring and the outcomes of that mentoring, namely, career success and career satisfaction, for the faculty. Moreover, the study aims to reveal whether psychosocial mentoring or career mentoring has a greater impact on faculty outcomes.

\section{Literature Review}

Faculty mentoring can be grouped into three categories: faculty-undergraduate student mentoring relationship, faculty-graduate student mentoring relationship and the mentoring relationships among faculty members (Lechuga, 2011). Mentoring in higher education institutions is traditionally formed as either an informal or a 
planned program. In formal mentoring programs, novice faculty works with experienced faculty in a one-to-one program (Darwin \& Palmer, 2009). Faculty mentoring relationship spreads over several years, during which the relationships go through initiation, cultivation, separation and redefinition phases (Kram, 1983). Initiation phase lasts for about a year, and depending on the efficiency of the mentor, the support given to the protégé, and counseling competence, the protégé starts to respect and admire the more experienced organizational member. In this phase, both the mentor and the protégé begin to establish some expectations regarding a future mentoring relationship. During the cultivation phase, which occurs in the following two to five years, the mentor and the protégé test the expectations formed in the first phase. The mentor generally deals with the protégé's career mentoring and psychosocial mentoring. The career-related function of mentoring relationship enables the protégé to develop his or her career by learning everything related to work and to improve within the organization. The psychosocial function, on the other hand, refers to the aspect of mentoring which is affected by human values. These values are related to the psychosocial development of the protégé and aim at empowering the person in terms of competency, identity and professional role. During the separation phase, which lasts between six months and two years, the mentor and the protégé reevaluate the need for maintaining the mentoring relationship as the protégé becomes less dependent on the mentor (Mansson \& Myers, 2012). During this phase, the mentor starts to provide less career and psychosocial mentoring. Finally, in the redefinition phase, the relationship changes from mentoring relationship into a peer or friendship relationship.

\subsection{Faculty Mentoring in Turkish Universities}

The current study reflects the perspectives of both the mentor and the protégé. All faculty members in the study (research assistant, assistant professor, associate professor and professor) were asked to evaluate the mentoring relationships during their career with respect to career satisfaction and career success. In the Turkish higher education system, there is usually a formal advisor-advisee relationship during undergraduate education. The advisor offers counseling on course selection, preventing and correcting errors in routine matters, course add/drop and exam process. As the number of students in undergraduate programs is high, a mentoring relationship may not be provided at this stage. During graduate education, the formal advisor-advisee relationship specified by Turkish Higher Education Institution turns into a mentor-protégé mentoring relationship in time. At this stage, the protégé attends conferences with the advisor or takes part in projects that the advisor manages. The graduate student receives help not only from the advisor but also from other faculty members in the same university or, although rare, from faculty members in other universities. The graduate student may even become a faculty member with the proposal of the advisor if the legal requirements are met. After completing the doctoral degree, the graduate student may end the advisor-advisee relationship as also stated in Kram's (1983) approach. If the graduate student becomes a faculty member, then the advisor-advisee relationship mostly continues in the form of faculty-faculty relationship. The mentoring relationship cannot continue if the graduate student starts working somewhere other than a university setting upon finishing the masters or doctorate program.

\subsection{Mentoring Outcomes}

Although some studies have been conducted so far to evaluate the negative outcomes of a mentoring relationship, it is more likely to encounter studies explaining the positive outcomes (Gibson, 2004). In their meta-analysis, Allen, Eby, Poteet, and Lentz (2004) reveal that protégé benefits from the mentor, and that the amount of psychosocial and career mentoring is the predictor of objective and subjective career outcomes. Ensher et al. (2001) argue that since mentoring relationship leads to numerous positive career outcomes such as more job and career satisfaction, better organizational socialization, higher income, and faster promotion rate compared to a protégé without a mentor, it has gained popularity in recent years.

When recent studies on faculty mentoring outcomes are examined, it is seen that these studies mostly focus on the protégé and such outcomes as satisfaction, increase in the number of publications and presentations, socialization of the student and improvement in student's skills (Lechuga, 2011; Lunsford, 2012; Mansson \& Myers, 2012; Ogunyemi, Solnik, Alexander, Fong, \& Azziz, 2010; Paglis, Green, \& Bauer, 2006; Webb, Wangmo, Ewen, Teaster, \& Hatch, 2009). Lumpkin (2011) summarizes the potential benefits of faculty mentoring as follows: (i) it facilitates the recruitment, retention and improvement of the faculty; (ii) it socializes the protégé into the culture of the academic unit; (iii) it increases collegial cooperation and forms a network between the protégé and the mentors; (iv) it increases the productivity of the protégé and the mentor; and (v) it encourages career advancement and professional improvement for both the protégé and the mentor. Cavendish (2007), on the other hand, used the variables of relational satisfaction, perceived time-to-degree, research self-efficacy and relational quality as the outcomes of mentoring relationship. 
In the studies which examined faculty mentoring relationship and which used 'satisfaction' as the protégé outcome, career satisfaction was overlooked although mentor satisfaction and job satisfaction were measured. However, as faculty mentoring relationship enables the protégé to advance in career, it also enhances career satisfaction of the protégé. Career satisfaction involves the feeling of satisfaction or dissatisfaction about one's career (Lounsbury, Steel, Gibson, \& Drost, 2008) and the subjective evaluation of one's own career development (Hofmans, Dries, \& Pepermans, 2008). According to Carr, Bickel, and Inui (2003), an instructor who has a mentor feels more secure compared to those without a mentor; are more productive researchers; receive greater support; and experience higher career satisfaction. Two hypotheses developed in relation to these themes are;

\section{Hypothesis 1a: Career mentoring positively affects career satisfaction.}

\section{Hypothesis 1b: Psychosocial mentoring positively affects career satisfaction.}

The relationship between mentoring and career success at workplace has long been investigated (Allen et al., 2004; Ensher et al., 2001; Judge, Cable, Boudreau, \& Bretz, 1995; Ng, Eby, Sorensen, \& Feldman, 2005). Career success is defined in terms of the positive psychological and work-related outcomes produced as a result of one's work experiences (Seibert \& Kraimer, 2001). In few studies examining the relationship between mentoring and student outcomes in higher education (Lunsford, 2012; Ogunyemi et al., 2010), such outcomes as the number of publications and presentations and the rate of progress have been viewed as the academic success indicators. In Dreher and Ash's study (1990) on 440 graduate students at two US public universities, a direct positive relationship was identified between mentoring and career success. In an empirical study, Mansson and Myers (2012) examined the perceptions of both $636 \mathrm{PhD}$ students and $141 \mathrm{PhD}$ advisors regarding the mentoring relationship, and they found that mentoring relationship is significant in terms of the academic success of the advisee. Yet, no studies have yet explored the relationship between mentoring functions and career success of the faculty member (mentor or protégé). The current study focuses on career success, and it is hypothesized that:

H2a: Career mentoring positively affects career success.

H2b: Psychosocial mentoring positively affects career success.

\section{Methodology}

\subsection{Participants}

Since the focus of the study is the mentoring outcomes for faculty members, potential participants were identified using the publicly available data on the websites of Turkish universities. Faculty members in Turkish universities involve research assistants, instructors, assistant professors, associate professors and professors. Researchers in the current study reached 1.100 email addresses one by one from the websites of the universities. An e-questionnaire was sent to 1.100 faculty members along with an invitation letter. Two weeks after the invitation letters were sent, faculty members were sent a reminder note. A total of 445 valid questionnaires were returned. One month was given to the respondents to return the questionnaires so that the problems that may arise due to long waiting time may be avoided.

\subsection{Measures}

In the current study, in order to assess the career-related and psychosocial functions, a mentoring questionnaire with a total of 31 items was used. In this questionnaire, 29 of the items were developed by Noe (1988), while two items were developed by Anafarta, Kuruuzum, and Sarvan (2003). The respondents were required to read each item and assess their experience with their mentor on a 4 point scale ( $1=$ not at all; $2=$ to some extent; $3=$ to a great extent; $4=$ to a very great extent). Two primary mentoring domains were included: psychosocial mentoring and career mentoring. While psychosocial mentoring includes sub-constructs such as counseling, role-modeling, acceptance and confirmation, and friendship; career mentoring includes coaching, protection, exposure and visibility, challenging assignments and sponsorship sub-constructs. Cronbach's alpha obtained for these two primary domains (psychosocial functions and career-related functions) and nine sub-constructs, and the number of items for each domain and sub-construct were given in Table 1. Cronbach's alpha shows that reliability coefficients for all constructs are large enough (Cronbach, 1990). Cronbach's alpha was not calculated for the sponsorship sub-construct as there is only one item under this construct. 
Table 1. Reliability coefficients for the mentoring scale

\begin{tabular}{lcc}
\hline Domains & Cronbach's alpha & Number of items \\
\hline Psychosocial mentoring & $\mathbf{0 . 9 3}$ & $\mathbf{1 6}$ \\
Counseling & 0.90 & 6 \\
Role-modeling & 0.85 & 4 \\
Acceptance and confirmation & 0.79 & 4 \\
Friendship & 0.79 & 2 \\
Career mentoring & $\mathbf{0 . 9 4}$ & $\mathbf{1 5}$ \\
Coaching & 0.88 & 6 \\
Protection & 0.82 & 3 \\
Exposure and visibility & 0.88 & 3 \\
Challenging assignments & 0.78 & 2 \\
Sponsorship & - & 1 \\
General reliability & $\mathbf{0 . 9 6}$ & $\mathbf{3 1}$ \\
\hline
\end{tabular}

Validity was tested through exploratory and confirmatory factor analysis. Varimax rotation was conducted. The results of the exploratory factor analysis are given in Table 2 . As seen in the table, all mentoring functions are represented by two factors, explaining approximately $67 \%$ of variation, which is considered to be an acceptable rate (Hair, Anderson, Tatham, \& Black, 1998). Factor 1 includes the mentoring functions of role modelling, acceptance and confirmation, counseling, and friendship, and it explains $40 \%$ of total variation. Factor 2 represents protection, challenging assignments, coaching, exposure and visibility, and sponsorship dimensions of the career-related mentoring function, and it explains $27 \%$ of total variation. Factor loadings are above .50 in both dimensions.

Confirmatory factor analysis was conducted with LISREL VIII (Jöreskog \& Sörbom, 2001), and it was found that the model with two primary domains and nine sub-constructs fits the data well (Hair et al., 1998). Fit indices are $\chi^{2}=66.83(\mathrm{df}=18, \mathrm{p}=0.000), \mathrm{RMSEA}=0.079, \mathrm{GFI}=0.97$ and $\mathrm{AGFI}=0.92$. Tests of validity and reliability yielded results quite similar to those of Noe's (1988) study. The composite reliability of each construct is one of the principal measures used in assessing the measurement model, and the commonly used threshold value for acceptable composite reliability is .70 (Hair et al., 1998). The construct reliability values for psychosocial and career mentoring are .86 and .89 , respectively. AVE value for psychosocial mentoring and career mentoring were found to be .68 and .76 , respectively. All indicators suggest that the data fit quite well to the two-dimensional mentoring model.

Greenhaus, Parasuraman, and Wormley's (1990) five-item career satisfaction scale was used to measure career satisfaction of the faculty members participating in the study. The scale is composed of items such as "I am satisfied with the progress I have made regarding the accomplishment of my promotion objectives", and "I am satisfied with the progress I have made regarding the development of new skills". The reliability of the career satisfaction scale was measured with Cronbach's alpha. Cronbach's alpha of the career satisfaction scale for this study is .85 .

A six-item scale developed by Anafarta, Kuruuzum, and Sarvan (2003) was used to measure career success of faculty members in the current study. The scale includes items which can be used by faculty members to make a comparison between themselves and their colleagues who have the same level of seniority. The number and quality of academic publications, the pace of advancing in career, recognition and acceptance in professional circles, success in educational activities, and career mentoring were taken as basis in the measurement of career success. 
Table 2. The rotated factor loadings of mentoring functions

\begin{tabular}{|c|c|c|}
\hline \multirow[b]{2}{*}{ Items } & \multicolumn{2}{|c|}{ Factor loadings } \\
\hline & $\begin{array}{c}\text { Factor } \\
1\end{array}$ & $\begin{array}{c}\text { Factor } \\
2\end{array}$ \\
\hline 1. Mentor has shared the history of his/her career with me. (Coaching) & & .63 \\
\hline 2. Mentor has encouraged me to prepare for advancement. (Coaching) & & .56 \\
\hline 3. Mentor has encouraged me to try new ways of behaving in my job. (Acceptance \& Confirmation ) & .60 & \\
\hline 4. I try to imitate the work behavior of my mentor. (Role Model) & .51 & \\
\hline 5. I agree with my mentor's attitudes and values regarding education. (Role Model) & .60 & \\
\hline 6. I respect my mentor. (Role Model) & .68 & \\
\hline 7. I will try to be like my mentor when I reach a similar position in my career. (Role Model) & .67 & \\
\hline 8. My mentor has demonstrated good listening skills in our conversations. (Counseling) & .66 & \\
\hline $\begin{array}{l}\text { 9. My mentor has discussed my questions or concerns regarding feelings of competence, commitment to } \\
\text { advancement, relationships with peers and supervisors or work/ family conflicts. (Counseling) }\end{array}$ & .56 & \\
\hline $\begin{array}{l}\text { 10. My mentor has encouraged me to talk openly about anxiety and fears that detract me from my work. } \\
\text { (Counseling) }\end{array}$ & .52 & \\
\hline $\begin{array}{l}\text { 11. My mentor has conveyed empathy for the concerns and feelings I have discussed with him/her. } \\
\text { (Counseling) }\end{array}$ & .70 & \\
\hline 12. My mentor has kept feelings and doubts I shared with him/her in strict confidence (Counseling) & .73 & \\
\hline 13. My mentor has conveyed feelings of respect for me as an individual. (Acceptance \& Confirmation) & .71 & \\
\hline $\begin{array}{l}\text { 14. Mentor reduced unnecessary risks that could threaten the possibility of receiving a promotion } \\
\text { (Protection) }\end{array}$ & & .57 \\
\hline $\begin{array}{l}\text { 15. Mentor helped me finish assignments/tasks or meet deadlines that otherwise would have been difficult } \\
\text { to complete (Protection) }\end{array}$ & & .51 \\
\hline $\begin{array}{l}\text { 16. Mentor assigned responsibilities to me that have increased my contact with people in the district who } \\
\text { may judge my potential for future advancement (Exposure \& Visibility ) }\end{array}$ & & .74 \\
\hline 17. Mentor helped me meet new colleagues (Exposure \& Visibility ) & & .77 \\
\hline $\begin{array}{l}\text { 18. Mentor gave me assignments that increased written and personal contact with university administrators } \\
\text { (Exposure \& Visibility ) }\end{array}$ & & .77 \\
\hline 19. My mentor has shared personal experiences as an alternative perspective to my problems (Counseling) & .67 & \\
\hline $\begin{array}{l}\text { 20. Mentor provided me with support and feedback regarding my performance as an educator (Challenging } \\
\text { Assignments) }\end{array}$ & & .51 \\
\hline 21. Mentor gave me assignments that present opportunities to learn new skills (Challenging Assignments) & & .72 \\
\hline 22. My mentor suggested specific strategies for accomplishing work objectives (Coaching) & & .56 \\
\hline 23. Mentor shared ideas with me (Coaching) & & .50 \\
\hline $\begin{array}{l}\text { 24. Mentor has given me assignments or tasks in my work that prepare me for an administrative position } \\
\text { (Sponsorship) }\end{array}$ & & .71 \\
\hline 25. Mentor suggested specific strategies for achieving my career goals (Coaching) & & .58 \\
\hline 26. My mentor has invited me to join him/her for lunch (Friendship) & .69 & \\
\hline $\begin{array}{l}\text { 27. My mentor has asked for suggestions concerning problems she/he has encountered at school } \\
\text { (Acceptance \&Confirmation) }\end{array}$ & .65 & \\
\hline 28. My mentor has interacted with me socially outside of work (Friendship) & .75 & \\
\hline $\begin{array}{l}\text { 29. My mentor has assumed responsibility in situations that would have adverse effects (Protection) } \\
\text { (Added by the authors) }\end{array}$ & & .63 \\
\hline 30. My mentor has praised my talents and skills.(Acceptance \& Confirmation) (Added by the authors) & .51 & \\
\hline
\end{tabular}


31. Mentor gave me feedback regarding my performance in my present job (Coaching)

Eigenvalue

The scale includes such phrases as "in terms of the number of academic publications" or "in terms the quality of academic publications". The respondents were required to assess their experience on a 3 point scale $(1=$ lower than my colleagues; $2=$ equal to my colleagues; $3=$ higher than my colleagues). Cronbach's alpha coefficient for the career success scale is .76 .

\subsection{Data Analysis}

To test the postulated hypotheses, correlation analyses and structural equation modeling were utilized. The structural relationships between mentoring, career satisfaction and career success were analyzed using LISREL VIII (Jöreskog \& Sörbom, 2001). Structural Equation Modeling (SEM) can effectively be conceptualized as a comparative technique in which models are evaluated against other constructed models to determine the best fit from the derived data (Anderson \& Gerbing, 1988). The reason for using SEM in the current study is that it enables one to see various reason-result relationships at the same time, and it tests the appropriateness of the hypothesized model to the data.

\section{Results}

Participants in the current study were professors (12.5\%), associate professors (11.6\%), assistant professors (25.5\%), research assistants (33.2\%), and research assistants with a $\mathrm{PhD}$ degree and instructors (17.2\%). 47.7\% of participants are female and $52.3 \%$ are male. The rate of respondents who never had a mentor is $10.8 \%$. The reason for the high rate of respondents reporting mentoring is the formal assignment of an advisor to every young faculty member during the masters' and doctoral studies in the academic institutions in Turkey. If any faculty member reports to have received no mentoring during his or her academic life, this means that no support was provided by a formal advisor. The rate of those who stated that they had only one mentor is $29.2 \%$, while the rate of those with two mentors is $30.3 \%$. Faculty members with three or more mentors make up $29.7 \%$ of the participants. While the rate of formal mentoring is $69.4 \%$, informal mentoring has a rate of $30.6 \%$. The duration of mentoring ranges from 1 to 30 years, and the average length of mentoring is 4.5 years. Faculty members state that they experience mentoring relationship mainly during their masters' and doctorate studies. The rate of those who said that mentoring relationship continued after completing the doctoral degree is only $8 \%$. $36.9 \%$ of participants have been working at the same university for less than five years, while $26.8 \%$ of participants have been working at the same university for five to ten years. The rate of those who have been working at the same institution for more than ten years is $36.3 \%$.

Pearson correlations between career and psychosocial functions which are used to measure the faculty mentoring relationship in the study are given in Table 3. As seen in the table, the correlations among psychosocial functions (counseling, role-modeling, acceptance and confirmation, and friendship) are strong and ranges from .40 to .70 . There is also quite a strong correlation among career functions (protection, coaching, sponsorship, exposure and visibility, challenging assignments). However, the correlations between career functions and psychosocial functions are statistically significant and moderate. Also, career and psychosocial mentoring functions have significant and low correlations with both career satisfaction and career success. 
Table 3. Correlations among research variables $(n=445)$

\begin{tabular}{|c|c|c|c|c|c|c|c|c|c|c|}
\hline & 2 & 3 & 4 & 5 & 6 & 7 & 8 & 9 & Csat & Csuc \\
\hline 1.Counseling & $.70^{* *}$ & $.69^{* *}$ & $.57^{* *}$ & $.47^{* *}$ & $.49^{* *}$ & $.38^{* *}$ & $.46^{* *}$ & $.39^{* *}$ & $.23 * *$ & $.33 * *$ \\
\hline 2.Role-modeling & 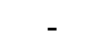 & $.63^{* *}$ & $.40^{* *}$ & $.51^{* *}$ & $.53^{* *}$ & $.42^{* *}$ & $.47^{* *}$ & $.28^{* *}$ & $.26^{* *}$ & $.27 * *$ \\
\hline $\begin{array}{l}\text { 3.Acceptance and } \\
\text { confirmation }\end{array}$ & & - & $.62 * *$ & $.54 * *$ & $.51^{* *}$ & $.43 * *$ & $.49 * *$ & $.30^{* *}$ & $.25^{* *}$ & $.28^{* *}$ \\
\hline 4.Friendship & & & - & $.39 * *$ & $.38^{* *}$ & $.41^{* *}$ & $.37 * *$ & $.33^{* *}$ & $.22 * *$ & $.25 * *$ \\
\hline 5.Coaching & & & & - & $.70^{* *}$ & $.69^{* *}$ & $.71 * *$ & $.59 * *$ & $.35^{* *}$ & $.26^{* *}$ \\
\hline 6.Protection & & & & & - & $.62^{* *}$ & $.63 * *$ & $.50^{* *}$ & $.32 * *$ & $.25^{* *}$ \\
\hline 7.Exposure and Visibility & & & & & & - & $.70^{* *}$ & $.63 * *$ & $.30^{* *}$ & $.24 * *$ \\
\hline 8.Challenging Assignments & & & & & & & - & $.53 * *$ & $.34 * *$ & $.23 * *$ \\
\hline 9.Sponsorship & & & & & & & & - & $.24 * *$ & $.22 * *$ \\
\hline Csat & & & & & & & & & - & $.45^{* *}$ \\
\hline
\end{tabular}

Note. Csat: career satisfaction; Csuc: career success. ${ }^{* *} \mathrm{p}<.01$

In Turban and Dougherty's (1994) study involving 147 managers, the correlation between both psychosocial and career mentoring, and perceived career success was found to be .42. Bozionelos, Bozionelos, Kostopoulos, and Polychroniou (2011) investigated the relationship between mentoring and career success, and between mentoring and organizational dependence on 194 employees in England, and they found that the correlation between mentoring and career success is .31. In Blickle, Witzki and Schneider's (2008) study, the correlation between career satisfaction and the mentoring received was found to be .34 .

\subsection{Hypothesis Testing}

To test the research hypotheses, path analysis was performed using LISREL VIII (Jöreskog \& Sörbom, 2001). The results revealed that the research model has a good fit to the data based on the indices given in the literature on SEM (Hair et al., 1998; $\chi 2=601.93, \mathrm{p}=.13$; RMSEA=.078; GFI=.95; AGFI=.92.).

The resulting significant standardized parameter estimates were presented in Table 4 . All the path coefficients in the research model are significant. Career mentoring has an impact on career satisfaction $(\beta=.32, \mathrm{p}<.01)$, which means that hypothesis H1a is accepted. Psychosocial mentoring affects career satisfaction as well; thus, hypothesis $\mathrm{H} 1 \mathrm{~b}$ is also accepted. It was found that the degree of career and psychosocial mentoring offered by faculties has a positive effect on career success (Table 4), meaning that the hypotheses H2a and H2b are also accepted. Table 4 also shows that psychosocial mentoring affects career success more compared to career mentoring $(\beta=.41, \mathrm{p}<.01)$.

Table 4. The results of the constructed model

\begin{tabular}{ll}
\hline Paths and goodness of fit statistics & Standardized path estimates (t-value) \\
\hline Career mentoring $\rightarrow$ Career satisfaction & $.32(5.67)^{\mathrm{a}}$ \\
Psychosocial mentoring $\rightarrow$ Career satisfaction & $.21(3.64)^{\mathrm{b}}$ \\
Career mentoring $\rightarrow$ Career success & $.24(4.25)^{\mathrm{a}}$ \\
Psychosocial mentoring $\rightarrow$ Career success & $.41(5.53)^{\mathrm{a}}$ \\
$\chi 2,(\mathrm{p})$ & $601.93(0.013)^{\mathrm{b}}$ \\
RMSEA & .078 \\
GFI & .95 \\
AGFI & .92 \\
${ }^{\mathrm{a}} \mathrm{p}<.01,{ }^{\mathrm{b}} \mathrm{p}<.05$ & \\
\hline
\end{tabular}




\section{Discussion}

The present study examines the effect of mentoring in Turkish universities on faculty members' career satisfaction and career success. The results of the study reveal that academic mentoring and psychosocial mentoring have an impact on faculty members' career satisfaction and career success. According to the results of the path analysis, the relationship between psychosocial mentoring and career success is the strongest. Psychosocial mentoring affects career success more than career satisfaction. Similar results were obtained in the correlation analysis. The relationships between counseling, role modeling, and acceptance and confirmation subdimensions of psychosocial mentoring and career success are stronger than the relationships between the same subdimensions and career satisfaction.

The second strong relationship in the path analysis model is between career mentoring and career satisfaction. Career mentoring faculty members receive affects career satisfaction more compared to career success. The correlations between coaching, protection, exposure and visibility, challenging assignments and sponsorship subdimensions of career mentoring and career satisfaction are higher than those between the same subdimensions and career success. Mentoring relationship in a university setting is generally in the form of help that a faculty member gives to a graduate student or help that colleagues give each other. The counseling given by the faculty helps the new faculty adapt to the world of academia. It also facilitates the development of good habits, improves job satisfaction and productivity, vitalizes the faculty and keeps the faculty in the organization (Cunningham, 1999; Mathews, 2003; Schrodt, Cawyer, \& Sanders, 2003). Underhill (2006) reviewed 106 articles written between 1988 and 2004 on mentoring and mentoring research in the fields of nursing, education, business and psychology, and as also revealed by Allen et al. (2004), she found that mentoring has a little impact on protégé's income, while it has a moderate impact on job satisfaction, the number of promotions and promotion opportunities or expectations for advancement. In the study he carried out to reveal the extent of mentoring that $\mathrm{PhD}$ advisors provide, Lunsford (2012) found that psychosocial and career mentoring have a direct positive effect on the satisfaction with academic advisor.

Yet another finding in the current study is that only $8 \%$ of faculty members continue their relationship with the other faculty members. $92 \%$ of faculty members state that the mentoring relationship is over, which implies that faculty members in Turkish universities do not maintain their mentoring relationship for a long time during their doctorate studies. Particularly when the protégé completes his or her doctoral degree and becomes an assistant professor, mentoring relationship ends. This may be because a faculty member who is an assistant professor is also a mentor to younger protégés. All in all, faculty mentoring in Turkish universities mainly occurs during graduate studies (masters and doctorate), and such a relationship contributes positively to both the career success and career satisfaction of faculty members.

\subsection{Implications}

When the faculty members were asked about the type of the mentoring they receive, about $30 \%$ of them mentioned informal mentoring. The results of the current study revealed that although the main source of informal mentoring was said to be the faculty member, the following questions still remain to be answered: Are the faculty members experienced and senior, or peer? Are they from the same department or from another department? Are they from the same field of study? What type of mentor benefits the protégé most? Why does the protégé need an informal mentor, while there is a formal mentor? At what stage does the protégé need an informal mentor? As far as faculty mentoring studies are concerned, there are few studies focusing on mentoring network and the benefits provided. In future studies, researchers may examine the type of mentoring network and the benefits received from each network type.

Another implication of the study is that the majority of the faculty members do not continue the mentoring relationship following the graduate studies (masters and doctoral degree). Why does not a faculty member maintain the mentoring relationship for a long time? This may be because the protégé may feel academically competent upon completing doctoral degree and becoming an assistant professor. There is yet no finding supporting this hypothesis. Therefore, the reason why faculty members cannot maintain the mentoring relationship for a long time may be investigated through a qualitative research design.

In the current study, a cross-discipline comparison could not be made as the sample size was not sufficiently large while the SEM model was being developed. In other words, whether the level of mentoring in different disciplines creates a difference in career success and career satisfaction has not been examined. Whether the same SEM model functions differently in health, social and/or physical sciences may be tested through empirical studies. Many studies focus on junior faculty (mostly doctoral mentoring and its results), whereas the present study investigated the multi-dimensional aspects of mentoring. The findings of the study may also be of use to 
deans, department chairs, and researchers who wish to examine mentoring further.

\section{References}

Allen, T. D., Eby, L., Poteet, M. L., \& Lentz, E. (2004). Career benefits associated with mentoring for protégés: A meta analysis. Journal of Applied Psychology, 89, 127-136. http://dx.doi.org/10.1037/0021-9010.89.1.127

Anafarta, N., Kuruuzum, A., \& Sarvan, F. (2003). Testing factors of academic mentoring: The case of Turkish academic. Paper presented at the Twelfth Annual World Business Congress, in British Columbia, Canada.

Anderson, J. C., \& Gerbing, D. W. (1988). Structural equation modeling in practice: A review and recommended two step approach. Psychological Bulletin, 103, 411-423. http://dx.doi.org/10.1037/0033-2909.103.3.411

Blickle, G., Witzki, A. H., \& Schneider, P. B. (2009). Mentoring support and power: A three year predictive field study on protégé networking and career success. Journal of Vocational Behavior, 74, 181-189. http://dx.doi.org/10.1016/j.jvb.2008.12.008

Bozionelos, N., Bozionelos, G., Kostopoulos, K., \& Polychroniou, P. (2011). How providing mentoring relates to career success and organizational commitment. A study in the general managerial population. Career Development International, 16, 446-468. http://dx.doi.org/10.1108/13620431111167760

Carr, P. L., Bickel, J., \& Inui, T. S. (2003). Taking root in a forest clearing: A resource guide for medical faculty. Retrived from http://www.bu.edu/cms/www.bumc.bu.edu/busm-osa/files/Resource_Guide/Resource_Guide For_Faculty.pdf

Cavendish, S. E. (2007). Mentoring matters: the influence of social support and relational maintenance strategies on critical outcomes in doctoral education (Unpublished $\mathrm{PhD}$ thesis). University of Kentucky: Kentucky, USA. Retrieved from http://uknowledge.uky.edu/gradschool_diss/498

Cronbach, L. J. (1990). Essentials of Psychological Testing (5th ed.). New York: Harper Collins Publishers.

Cunningham, S. (1999). The nature of workplace mentoring relationships among faculty members in Christian higher education. The Journal of Higher Education, 70, 441-463. http://dx.doi.org/10.2307/2649310

Darwin, A., \& Palmer, E. (2009). Mentoring circles in higher education. Higher Education Research \& Development, 28, 125-136. http://dx.doi.org/10.1080/07294360902725017

Dreher, G. F., \& Ash, R. A. (1990). A comparative study of mentoring among men and women in managerial, professional, and technical positions. Journal of Applied Psychology, 75, 539-546. http://dx.doi.org/10.1037/0021-9010.75.5.539

Ensher, E. A., Thomas, C., \& Murphy, S. E. (2001). Comparison of traditional, stepahead, and peer mentoring on protégés support, satisfaction, and perceptions of career success: A social exchange perspective. Journal of Business and Psychology, 15, 419-438. http://dx.doi.org/10.1023/A:1007870600459

Gibson, S. K. (2004). Being mentored: The experience of women faculty. Journal of Career Development, 30, 173-188. http://dx.doi.org/10.1023/B:JOCD.0000015538.41144.2b

Greenhaus, J. H., Parasuraman, S. J., \& Wormley, W. M. (1990). Effects of race on organizational experiences, job performance evaluations, and career outcomes. Academy of Management Journal, 33, 64-86. http://dx.doi.org/10.2307/256352

Hair, J. F., Anderson, R. E., Tatham, R. L., \& Black, W. C. (1998). Multivariate Data Analysis (5th ed.). New Jersey: Pearson Education.

Hofmans, J., Dries, N., \& Pepermans, R. (2008). The career satisfaction scale: Response bias among men and women. Journal of Vocational Behavior, 73, 397- 403. http://dx.doi.org/10.1016/j.jvb.2008.08.001

Jöreskog, K. G., \& Sörbom, D. (2001). Lisrel 8: User's Reference Guide. Chicago: Scientific Software International.

Judge, T. A., Cable, D. M., Boudreau, J. W., \& Bretz, R. D. (1995). An empirical investigation of the predictors of executive career success. Personnel Psychology, 48, 485-519. http://dx.doi.org/10.1111/j.1744-6570.1995.tb01767.x

Kram, K. E. (1983). Phases of the mentor relationship. Academy of Management Journal, 26, 608-625. http://dx.doi.org/10.2307/255910

Lechuga, V. M. (2011). Faculty-graduate student mentoring relationships: Mentors' perceived roles and responsibilities. Higher Education, 62, 757-771. http://dx.doi.org/10.1007/s10734-011-9416-0 
Lounsbury, J. W., Steel, R. P., Gibson, L. W., \& Drost, A. W. (2008). Personal traits and career satisfaction of human resource professionals. Retrieved from http://info.ecareerfit.com/eCareerFit/CareerSatisfaction HRProfessionals_final2.pdf

Lumpkin, A. (2011). A Model for mentoring university faculty. The Educational Forum, 75, 357-368. http://dx.doi.org/10.1080/00131725.2011.602466

Lunsford, L. (2012). Doctoral advising or mentoring? Effects on student outcomes. Mentoring \& Tutoring: Partnership in Learning, 20, 251-270. http://dx.doi.org/10.1080/13611267.2012.678974

Madison, J., \& Huston, C. (1996). Faculty-faculty mentoring relationships: An American and Australian Perspective. NASPA Journal, 33, 316-324.

Mansson, D. H., \& Myers, S. A. (2012). Using mentoring enactment theory to explore the doctoral student-advisor mentoring relationship. Communication Education, 61, 309-334. http://dx.doi.org/10.1080/03634523.2012.708424

Mathews, P. (2003). Academic mentoring: enhancing the use of scarce resources. Educational Management Administration Leadership, 31, 313-334. http://dx.doi.org/10.1177/0263211X03031003007

Ng, T. W. H., Eby, L. T., Sorensen, K. L., \& Feldman, D. C. (2005). Predictors of objectives and subjective $\begin{array}{llll}\text { career success: A meta-analysis. Personnel Psychology, 58, 367-408. } & \text { A }\end{array}$ http://dx.doi.org/10.1111/j.1744-6570.2005.00515.x

Noe, R. A. (1988). An investigation of the determinants of successful assigned mentoring relationships. Personnel Psychology, 41, 457-478. http://dx.doi.org/10.1111/j.1744-6570.1988.tb00638.x

Ogunyemi, D., Solnik, J. M., Alexander, J., Fong, A., \& Azziz, R. (2010). Promoting residents' professional development and academic productivity using a structured faculty mentoring. Program, Teaching and Learning in Medicine: An International Journal, 22, 93-96. http://dx.doi.org/10.1080/10401331003656413

Paglis, L. L., Green, S. G., \& Bauer, T. N. (2006). Does adviser mentoring add value? A longitudinal study of mentoring and doctoral student outcomes. Research in Higher Education, 47, 451-476. http://dx.doi.org/10.1007/s11162-005-9003-2

Schrodt, P., Cawyer, C. S., \& Sanders, R. (2003). An examination of academic mentoring behaviors and new faculty members' satisfaction with socialization and tenure and promotion processes. Communication Education, 52, 17-29. http://dx.doi.org/10.1080/03634520302461

Seibert, S. E., \& Kraimer, M. L. (2001). The five-factor model of personality and career success. Journal of Vocational Behavior, 58, 1-21. http://dx.doi.org/10.1006/jvbe.2000.1757

Stanley, C. A., \& Lincoln, Y. S. (2005). Cross-race faculty mentoring. Change, 37, 44-50. http://dx.doi.org/10.3200/CHNG.37.2.44-50

Turban, D. B., \& Dougherty, T. W. (1994). Role of protégé personality in receipt of mentoring and career success. Academy of Management Journal, 37, 688-702. http://dx.doi.org/10.2307/256706

Underhill, C. M. (2006). The effectiveness of mentoring programs in corporate settings: A meta-analytical review of the literature. Journal of Vocational Behavior, 68, 292-307. http://dx.doi.org/10.1016/j.jvb.2005.05.003

Webb, A. K., Wangmo, T., Ewen, H. H., Teaster, P. B., \& Hatch, L. R. (2009). Peer and faculty mentoring for students pursuing a PHD in gerontology. Educational Gerontology, 35, 1089-1106. http://dx.doi.org/10.1080/03601270902917869

\section{Copyrights}

Copyright for this article is retained by the author(s), with first publication rights granted to the journal.

This is an open-access article distributed under the terms and conditions of the Creative Commons Attribution license (http://creativecommons.org/licenses/by/3.0/). 